С. В. Павлов, Ю. В. Нікітченко

\title{
Кардіопротекторна дія індукторів синтезу білка KLOTHO за умов гострого експериментального інфаркту міокарда
}

\author{
Запорізький державний медичний університет
}

Ключові слова: білок Klotho, вітамін D, Necrostatin-1, гострий інфаркт міокарда, кардіопротекція

Останніми десятиліттями в світі відзначається тенденція до неухильно зростаючого розповсюдження судинних захворювань, що зумовлено загальним старінням населення, збільшенням захворюваності на цукровий діабет, артеріальну гіпертензію й атеросклероз $[1,2]$. Серце та головний мозок є взаємопов'язаними органами-мішенями за судинної патології, клінічні варіанти якої (ішемічна хвороба серця, мозковий інсульт) продовжують лідирувати в смертності населення розвинених країн [3]. Киснева недостатність є основою різноманітних патологічних процесів у разі багатьох захворювань і критичних станів, часто спостерігається в клініці й $€$ однією з центральних проблем медицини. Зокрема, дефіцит кисню впливає на тяжкість перебігу ішемічного ушкодження головного мозку та серця, шокових і колаптоїдних станів, інфекційних i неінфекційних захворювань, стресових ситуацій, формування поліорганної недостатності [3].

Як відомо, клітини міокарда мають максимальну енергоємкість, оскільки здійснюють найнапруженішу роботу [1, 4]. Однак загальна кількість крові, що циркулює в серцевому м'язі, порівняно невелика, та покриття значної потреби клітин у кисні здійснюється за рахунок максимального вилучення кисню з оксигемоглобіну. Не випадково до 30 \% об’єму клітини займають мітохондрії [5].

У зв'язку з цим проводиться активне вивчення факторів, що впливають на гіпоксичне пошкодження в органах i тканинах, у тому числі нервової та сер-

(с) Колектив авторів, 2020 цево-судинної систем. Особливий інтерес представляють отримані в експерименті та в клініці нові дані, які свідчать про те, що циркулююча форма білка Klotho має здатність знижувати окиснювальні процеси через активацію FoxO і збільшення експресії супероксиддисмутази, впливати на процеси ендотеліальної інтеграції та клітинні функції [6], активувати процеси клітинної адаптації в умовах гіпоксії за рахунок впливу на HIF i HSP-білки [7-9].

3 іншого боку, Klotho дефіцит у свою чергу збільшує окиснювальний стрес і робить клітини більш сприятливими до нього. Саме тому антиоксиданти, потенційно корисні для переривання цього негативного процесу, за рахунок активізації виробництва Klotho посилюють антиоксидантні властивості [7, 9]. Крім того, антиоксиданти пригнічують експресію та синтез білків Klotho й інших факторів ендогенної цитопротекції, саме тому 3'явились дані щодо недоцільності призначення антиоксидантної терапії в гострому періоді ішемії клітин серця.

Сьогодні в лікуванні захворювань серцево-судинної системи гіпоксичного генезу широко використовуються препарати, що відновлюють кровоток, а також препарати, які впливають на метаболізм клітини, а саме, на окремі ланки адаптаційних молекулярно-біохімічних реакцій. Відносно останніх препаратів накопичено багато експериментальних і клінічних даних щодо їхньої ефективності. Однак 3 точки зору доказової медицини дія даних препаратів суперечлива та сумнівна. У зв'язку з цим йде активний пошук препаратів метаболітотропної дії $[7,8]$. 
Натепер активний пошук цитопротекторів йде за двома основними напрямами:

a) створення siRNA (вплив на експресію геному, активація синтезу білків шаперонів і білків ендогенної цитопротекції, регуляція іонних каналів);

б) пошук ксенобіотиків, фізичних агентів, здатних впливати на експресію та синтез факторів ендогенної цитопротекції (HIF-білки, HSP, білок Klotho).

Обидва ці шляхи є перспективними й актуальними. Особливий інтерес представляють способи фармакокорекції шляхом впливу на синтез та експресію білка Klotho, зокрема застосування індукторів (вітаміну D i Necrostatin-1) [9-11].

Мета дослідження - встановлення кардіопротекторної дії індукторів експресії та синтезу білків Klotho (вітамін D, Necrostatin-1) за умов моделювання експериментального інфаркту міокарда (IM).

Матеріали та методи. Експериментальну частину роботи виконано на 40 статевозрілих щурах-самцях масою 170-210 г. Експериментальні тварини були отримані з розплідника ДУ «Інститут фармакології та токсикології НАМНУ». Усі експериментальні дослідження проводили 3 дотриманням основних положень Європейської конвенції про охорону хребетних тварин, що використовуються 3 експериментальними та іншими науковими цілями (Страсбург, 1986 р.). Дрібновогнищевий гострий інфаркт міокарда (ГІМ) моделювали шляхом введення впродовж 4 діб коронароспазмуючого агента - пітуїтрину (1 од/кг підшкірно) та адреноміметика ізопреналіну (200 мг/кг внутрішньом'язово) [12]. Досліджувані препарати Вітамін D (5000 МО/доба) (Гмбх Арцнайміттель, Німеччина) вводили внутрішньошлунково, Necrostatin-1 (Nec-1 $25 \mathrm{mg}$, Sigma-Aldrich) - 1 мг/кг внутрішньоочеревинно через 20 хв після введення ізадрину впродовж 4 днів. Досліджувані сполуки вводили в їхніх ефективних дозах, які були встановлені за допомогою ядерної оцінки регресії 3 використанням 3D-моделі.
Контрольною групою були тварини з моделюванням ГIM з внутрішньоочеревинним введенням фізіологічного розчину (Дарниця, Україна).

Для імуноферментних досліджень тканини серця гомогенізували на холоді, у сольовому ізотонічному середовищі $(0,15$ моль/л $\mathrm{KCl})$ за температури $+4{ }^{\circ} \mathrm{C}$, співвідношення тканина-сольовий розчин $1: 40$ і центрифугували 3000 об/хв, після чого відбирали надосадову рідину. У гомогенаті серця визначали концентрацію білка Klotho (Elabscience, № кат. E-EL-R2580), HSP70 білків (Enzo Life Science, № кат. ADI-EKS-715), маркера оксидативного пошкодження нуклеїнових кислот 8-гідрокси-2'деоксигуанозину, 2 деокси7,8-дигідро-8-оксогуанозину (8-OHdG, BioVendor, № кат. RSCN213101R).

Наявність ГIM підтверджували шляхом визначення в плазмі крові імунохемілюмінесцентним методом, Immulate 1000, тропоніну (Siemens), біохімічним методом загальної активності креатинфосфокінази (КФК, Cormay) та імуноферментним методом концентрації ST2 (cерцевий біомаркер, стимулюючий фактор росту, IL1R1, «The Pressage ST2 Assay» (Critical Diagnostics, № кат. BC-1065E).

Детекцію білка Klotho, HSP70 білків, 8-OHdG, ST2 здійснювали на імуноферментному комплексі Immuno Chem-2100 (США). Аналіз проводили 3 додаванням колориметричного реагенту, результуючий сигнал вимірювали спектрофотометрично за 450 нм. Концентрацію дослідних показників виражали в нг/мл [13].

Статистичну обробку результатів проводили з використанням програми «STATISTICA ${ }^{\circledR}$ for Windows 6.0» (StatSoftInc., №AXXR712D833214FAN5). Достовірність відмінностей проводили 3 використанням t-критерію Стьюдента.

Результати та їх обговорення. Моделювання ГІМ у експериментальних тварин відбувалось на тлі збільшення маркерів пошкодження серцевого м'яза (табл. 1) - тропоніну, активності загальної КФК. Важливо зазначити, що дослідні маркери мали тенденцію до збільшення в тварин усіх експериментальних груп порівняно з групою інтактних тварин. 
Маркери пошкодження міокарда (тропонін, загальна активність креатинфосфокінази, ST2) у плазмі крові тварин за моделювання гострого інфаркту міокарда та впливу вітаміну D i Necrostatin-1

\begin{tabular}{|l|c|c|c|}
\hline $\begin{array}{c}\text { Експериментальна група } \\
\text { тварин (n= 10) }\end{array}$ & $\begin{array}{c}\text { Тропонін, } \\
\text { нг/мл }\end{array}$ & $\begin{array}{c}\text { Активність креатин- } \\
\text { фосфокінази заг., } \\
\text { Од/л }\end{array}$ & ST2, нг/мл \\
\hline Інтактна група & $0,57 \pm 0,11$ & $51,40 \pm 2,70$ & $15,60 \pm 6,80$ \\
\hline $\begin{array}{l}\text { Гострий інфаркт міокарда } \\
\text { (контрольна група) }\end{array}$ & $8,80 \pm 1,30^{\star}$ & $210,57 \pm 4,70^{\star}$ & $42,80 \pm 4,40^{\star}$ \\
\hline $\begin{array}{l}\text { Гострий інфаркт міокарда + } \\
\text { Вітамін D (5000 Од/доба) }\end{array}$ & $6,40 \pm 1,10^{\star}$ & $196,70 \pm 5,80^{\star}$ & $28,40 \pm 3,70$ \\
\hline $\begin{array}{l}\text { Гострий інфаркт міокарда + } \\
\text { Кес-1 (1 мг/кг) }\end{array}$ & $7,20 \pm 1,40^{\star}$ & $200,60 \pm 4,90^{\star}$ & $27,10 \pm 4,60$ \\
\hline
\end{tabular}

Примітка. *p $\leq$ 0,05 порівняно з показником інтактної групи тварин.

Звертав на себе увагу різноспрямований характер вмісту маркера ST2 у плазмі. Як видно з таблиці 1 , концентрацію 35 нг/мл (діагностично значуща величина) та вище мали лише тварини контрольної групи. На тлі введення вітаміну D i Necrostatin-1 значення ST2 не досягали рівня 35 нг/мл. Відомо, що збільшення концентрації ST2 у разі несприятливого перебігу IM пов'язано з підвищенням вмісту розчинної форми маркера, яка утворюється за пошкодження кардіоміоцитів. У той самий час в умовах IM активуються гуморальні та клітинні ланки імунітету, що $\mathrm{\epsilon}$ необхідними для рубцювання зони некрозу, що й сприяє збільшенню рівня ST2. Значне збільшення ST2 у контрольної групи тварин можливо пов'язане $з$ декомпенсацією гемодинаміки й активацією прозапального статусу за умов ішемії міокарда [13, 14].
Дослідженнями останнього десятиріччя встановлено, що головна функція ST2 це потенціювання IL33, який забезпечує антигіпертрофічний та антифіброзуючий вплив на кардіоміоцити в умовах гіпоксії та біомеханічного розтягнення. Однак різке збільшення рівня ST2 призводить до пригнічення біологічних ефектів IL33. Зменшення накопичення ST2 під впливом дослідних сполук може розглядатись як один 3 імовірних механізмів їхньої кардіопротективної функції [14].

Крім того, експериментальна терапія вітаміном D i Necrostatin-1 призводила, як видно 3 таблиці 2, до статистично значущого збільшення вмісту в гомогенаті серця білка Klotho (відповідно на $76,3 \%$ і 78,8 \% порівняно з контролем). Відомо, що основними фундаментальними біологічними функціями білка Klotho, окрім антистаріння, є

Таблиця 2

Вліст білка Klotho, HSP 70-білків, 8-OHdG у гомогенаті серия тварин за моделювання гострого інфаркту міокарда та впливу вітаміну D i Necrostatin-1

\begin{tabular}{|l|c|c|c|}
\hline $\begin{array}{c}\text { Експериментальна група } \\
\text { тварин (n= 10) }\end{array}$ & $\begin{array}{c}\text { Білок KІоtho, } \\
\text { нг/мл }\end{array}$ & HSP 70 білки, нг/мл & $\begin{array}{c}\mathbf{8 - O H d G , ~} \\
\text { нг/мл }\end{array}$ \\
\hline Інтактна група & $6,78 \pm 0,82$ & $4,10 \pm 0,11$ & $1,20 \pm 0,05$ \\
\hline $\begin{array}{l}\text { Гострий інфаркт міокарда } \\
\text { (контрольна група) }\end{array}$ & $1,14 \pm 0,32^{\star}$ & $0,41 \pm 0,07^{\star}$ & $15,40 \pm 0,46^{\star}$ \\
\hline $\begin{array}{l}\text { Гострий інфаркт міокарда + } \\
\text { Вітамін D (5000 Од/доба) }\end{array}$ & $4,80 \pm 0,67^{\star \star}$ & $2,40 \pm 0,13^{\star \star}$ & $9,47 \pm 1,40^{\star \star}$ \\
\hline $\begin{array}{l}\text { Гострий інфаркт міокарда + } \\
\text { ес-1 (1 мг/кг) }\end{array}$ & $5,40 \pm 0,52^{\star \star}$ & $1,50 \pm 0,09^{\star \star}$ & $6,80 \pm 1,80^{\star \star}$ \\
\hline
\end{tabular}

Примітка. *p $\leq$ 0,05 порівняно з показником інтактної групи тварин, **p $\leq$ 0,05 порівняно з показником контрольної групи тварин. 
антиоксидантні ефекти, пригнічення окисного та нітрозуючого стресів, регуляція іонного гомеостазу, модулюючий вплив на експресію глобальних факторів транскрипції, а саме, збільшення фосфорилювання FoxO3. У свою чергу FoxO3 регулює синтез марганець-супероксиддисмутази (MnSOD), ензиму мітохондріального антиоксидантного захисту в клітинах. Показано, що надмірна експресія білка Klotho зменшує розвиток $\mathrm{H}_{2} \mathrm{O}_{2}$-індукованого апоптозу/некрозу за рахунок зменшення окисної деструкції ДНК і РНК $[7,15,16]$.

Дійсно, застосування індукторів синтезу білка Klotho призводило до обмеження окиснювального пошкодження нуклеїнових кислот, що відображалось значним порівняно з контролем зниженням концентрації 8-OHdG як на тлі призначення вітаміну D (на 38,5 \%), так i Necrostatin-1 (на 55,8 \%). На нашу думку, здатність досліджувальних сполук зменшувати накопичення в тканині серця 8-OHdG може бути можливим механізмом їхнього впливу на процеси клітинної загибелі в умовах гіпоксії.

Низкою експериментальних досліджень було встановлено, що активація синтезу білка Klotho в умовах гіпоксичного пошкодження клітин відбувається паралельно зі збільшенням синтезу HSP70 білків. 3 одного боку, за рахунок своєї шаперонної функції HSP70 білки в умовах оксидативного стресу стабілізують молекулу Klotho-білка; з іншого, Klotho стимулює входження HSP-білків у клітину, що в умовах інтенсифікації окисного та нітрозуючого стресів забезпечує захист структурних i функціональних властивостей макромолекул. Ці дані цілком узгоджуються з отриманими нами результатами [17-19]. На тлі введення вітаміну D і Necrostatin-1 відбувалося суттєве збільшення вмісту в гомогенаті серця HSP 70 білків (відповідно на 83,0 \% і 72,6 \%) порівняно 3 контрольною групою.
Таким чином, проведеним нами дослідженням була встановлена здатність індукторів синтезу білка Klotho покращувати метаболізм серцевого м'яза в умовах його ішемічного пошкодження. Так, на тлі експериментальної терапії вітаміном D (5000 Од/доба внутрішньошлунково) i Necrostatin-1 (1 мг/кг внутрішньоочеревинно) відбувалось статистично вірогідне зниження в плазмі крові вмісту маркера ST2 на тлі збільшення в гомогенаті серця концентрації білка Klotho та HSP70-білків. Крім того, позитивна дія досліджуваних сполук проявлялась їхньою здатністю обмежувати явища окисного стресу, знижуючи концентрацію в гомогенаті 8-OHdG.

Отримані експериментальні дані зумовлюють перспективність подальших досліджень у цьому напрямі. Особливий інтерес викликає дослідження здатності вітаміну D i Necrostatin-1 впливати на процеси клітинної загибелі та її тип (некроз/апоптоз).

\section{Висновки}

1. Моделювання ГIМ у щурів на 4 добу експерименту призводить до статистично вірогідного збільшення вмісту в плазмі крові маркерів пошкодження міокарда (тропоніну, ST2) та загальної активності КФК на тлі значного зменшення в гомогенаті серця концентрації білка Klotho, HSP70білків. Подібні патобіохімічні зміни відбувались на тлі приросту 8-OHdG.

2. За умов введення вітаміну D (5000 Од/ доба) i Necrostatin-1 (1 мг/кг) зменшувалося накопичення в плазмі крові маркера ST2 (менше ніж 35 нг/ мл) на тлі статистично значущого збільшення вмісту в гомогенті серця білка Klotho відповідно на 76,3\% і 78,8 \% порівняно з контролем.

3. Протективна дія індукторів синтезу білка Klotho проявлялась зменшенням концентрації 8-OHdG як на тлі застосування вітаміну D (на $38,5 \%$ ), так і Necrostatin-1 (на 55,8 \%).

1. Сравнительная характеристика профилактики сердечно-сосудистых заболеваний в Украине и Европе по данным исследования EUROASPIRE IV: госпитальная линия. В. Н. Коваленко, М.Н.Долженко, Е. Г. Несукай и др. Український кардіологічний журнал. 2015. № 4. С. 17-24.

2. On behalf of EUROACTION PLUS Study Group. Effectiveness of a preventive cardiology programme for high CVD risk persistent smokers: The EUROACTION PLUS trial. C. Jennings, K. Kotseva, D. DeBacquer et al. Eur. Heart J. 2014. V. 35. P. 1411-1420. 
3. EUROASPIRE IV : A European Society of Cardiology survey on the life style, risk factor and therapeutic management of coronary patients from 24 European countries. K. Kotseva, D. Wood, G. DeBacker et al. Eur. J. Preventive Cardiology. 2015.

4. World Health Organization. The world health report 2002. Reducing Risks, Promoting Healthy Life. Geneva, 2002.

5. Мойбенко О. О., Досенко В. Э., Пархоменко О. М. Эндогенные механизмы кардиопротекции как основа патогенетической терапии заболеваний сердца. Киев : Наукова думка, 2008. 520 с.

6. Pavlov S., Belenichev I. Molecular and Biochemical Aspects of the Neuroprotective Effect of the Selective Estrogen Receptor Modulator Tamoxifen in a Model of Acute Cerebral Ischemia. Neurochemical Journal. 2014. V. 8, № 1. P. 28-32.

7. Pavlov S., Pakholchuk O., Berezin A. Emerging Role of the Fibroblast Growth Factor 23/Klotho Axis in Cardiovascular and Metabolic Conditions: A Narrative Review. Journal of Biochemical Technology. 2020. Issue 2. P. 1-9.

8. Павлов С. В., Левченко К. В. Вплив естрогенів та селективних модуляторів естрогенових рецепторів на серцево-судинну систему. Вісник проблем біології і медицини. 2016. Т. 130, Вип. 2. С. 40-43.

9. Pavlov S., Nikitchenko Y., Tykhonovska M. The impact of the chemical agents of different pharmacological groups on the Klotho protein concentration in the cardiomyocyte and neurocyte suspension in 120 minute hypoxia in vitro. Georgian Medical News. 2020. № 9 (306). P. 184-188.

10. Necrostatin-1 Attenuates Cisplatin-Induced Nephrotoxicity Through Suppression of Apoptosis and Oxidative Stress and Retains Klotho Expression. Yichun Ning, Yiqin, Jing Chen et al. Front. Pharmacol. 2018. V. 19. https://doi.org/10.3389/fphar.2018.00384.

11. The Role of Vitamin D in the FGF23, Klotho, and Phosphate Bone-Kidney Endocrine Axis. M. R. Haussler, G. K. Whitfield, I. Kaneko et al. Rev Endocr Metab Disord. 2012. V. 13 (1). P. 57-69. https://doi.org/ 10.1007/s11154-011-9199-8.

12. Доклінічні дослідження лікарських засобів: методичні рекомендації; за ред. О. В. Стефанова. Київ : ВД «Авіцена», 2002. 527 с.

13. Allan V. J. Basic immunofluorescence. Protein localization by fluorescence microscopy: a practical approach. 2000. Oxford University Press, United Kingdom. P. 1-26.

14. Januzzi J. L., Mebaza A., Di Somma S. ST2 and Prognosis in Acutely Decompensated Heart Failure: The International ST2 Consensus Panel. The American Journal of Cardiology. 2015. V. 115 (7). https://doi.org/10.1016/j.amjcard.2015.01.037.

15. Klotho enhances FoxO3-mediated manganese superoxide dismutase expression by negatively regulating PI3K/AKT pathway during tacrolimus-induced oxidative stress. S. W. Lim, L. Jin, K. Luo et al. Cell Death \& Disease. 2017. P. e2972. https://doi.org/10.1038/cddis.2017.365.

16. Yuechi Xu and Zhongjie Sun. Molecular Basis of Klotho: From Gene to Function in Aging. Endocrine Reviews. 2015. V. 36 (2). P. 174-193.

17. Sugiura H., Yoshida T., Tsuchiya K. Klotho Reduces Apoptosis in Experimental Ischaemic Acute Kidney Injury via HSP-70. Nephrol Dial Transplant. 2010. V. 25 (1). P. 60-68.

18. Biological role of anti-aging protein Klotho. J. H. Kim, K. H. Hwang, K. S. Park et al. J. Lifestyle Med. 2015. V. 5. № 1. P. 1-6.

19. A klotho gene single nucleotide polymorphism is associated with the onset of stroke and plasma klotho concentration. S. Yokoyama, R. Oguro, K. Yamamoto et al. Aging (Albany NY). 2019. V. 11 (1). P. 104-114.

\section{С. В. Павлов, Ю. В. Нікітченко \\ Кардіопротекторна дія індукторів синтезу білка Klotho за умов гострого експериментального інфаркту міокарда}

Останніми десятиліттями в світі відзначається тенденція до неухильно зростаючого розповсюдження судинних захворювань, що зумовлено загальним старінням населення, збільшенням захворюваності на цукровий діабет, артеріальну гіпертензію й атеросклероз. Сьогодні в лікуванні захворювань серцево-судинної системи гіпоксичного генезу широко використовуються препарати, що відновлюють кровоток, а також препарати, які впливають на метаболізм клітини, а саме, на окремі ланки адаптаційних молекулярно-біохімічних реакцій. Відносно останніх препаратів накопичено багато експериментальних і клінічних даних щодо їхньої ефективності. Однак з точки зору доказової медицини ефекти даних препаратів суперечливі та сумнівні. У зв'язку з цим йде активний пошук препаратів метаболітотропної дії.

Мета дослідження - встановлення кардіопротекторної дії індукторів експресії та синтезу білків Klotho (вітамін D, Necrostatin-1) в умовах моделювання експериментального інфаркту міокарда.

Експериментальну частину роботи виконано на 40 статевозрілих щурах - самцях масою 170-210 г. Гострий інфаркт міокарда (ГІМ) моделювали шляхом введення впродовж 4 діб пітуїтрину (1 Од/кг підшкірно) та адреноміметика ізопреналіну (200 мг/кг внутрішньом'язово). Досліджувані препарати - 
Вітамін D (5000 МО/доба) (Гмбх Арцнайміттель, Німеччина) вводили внутрішньошлунково і Necrostatin-1 (Nec-1 25 mg, Sigma-Aldrich) - 1 мг/кг внутрішньоочеревинно через 20 хв після введення ізадрину впродовж 4 днів. Наявність ГІМ підтверджували шляхом визначення його маркерів у плазмі крові імунохемілюмінесцентним методом - Immulate 1000, тропоніну (Siemens), біохімічним методом - загальну активність креатинфосфокінази (КФК ) (Cormay) та імуноферментним методом - ST2 «The Pressage ST2 Assay» (Critical Diagnostics, № кат. BC-1065E). Детекцію білка Klotho, HSP70 білків, 8-OHdG, ST2 здійснювали на імуноферментному комплексі Immuno Chem-2100 (США).

Моделювання ГІМ в експериментальних тварин призводило до збільшення маркерів пошкодження серцевого м'яза тропоніну, активності загальної КФК. Важливо зазначити, що дослідні маркери мали тенденцію до збільшення в тварин усіх експериментальних груп порівняно з інтактною. На тлі введення вітаміну D i Necrostatin-1 значення ST2 не досягали рівня 35 нг/мл. Крім того, експериментальна терапія вітаміном D i Necrostatin-1 призводила до статистично значущого збільшення вмісту в гомогенаті серця білка Klotho (відповідно на 76,3 \% і 78,8 \% щодо контролю). Застосування індукторів синтезу білка Klotho сприяло обмеженню оксидативного пошкодження нуклеїнових кислот, що відображалось значним порівняно до контролю зниженням концентрації 8-OHdG як на тлі вітаміну D (на 38,5 \%), так і Necrostatin-1 (на 55,8 \%).

Отримані експериментальні дані зумовлюють перспективність подальших досліджень у цьому напрямі. Особливий інтерес викликає дослідження здатності вітаміну D i Necrostatin-1 впливати на процеси клітинної загибелі та її тип (некроз/апоптоз).

Ключові слова: білок Klotho, вітамін D, Necrostatin-1, гострий інфаркт міокарда, кардіопротекція

\section{С. В. Павлов, Ю. В. Никитченко \\ Кардиопротекторное действие индукторов синтеза белка Klotho в условиях острого экспериментального инфаркта миокарда}

В последние десятилетия в мире отмечается тенденция к неуклонно возрастающему распространению сосудистых заболеваний, что обусловлено общим старением населения, ростом заболеваемости сахарным диабетом, артериальной гипертензией и атеросклерозом. На сегодняшний день в лечении заболеваний сердечно-сосудистой системы гипоксичного генеза широко используются препараты, которые восстанавливают кровоток, а также препараты, влияющие на метаболизм клетки, а именно, на отдельные звенья адаптационных молекулярно-биохимических реакций. Относительно последних препаратов накоплено много экспериментальных и клинических данных об их эффективности. Однако с точки зрения доказательной медицины эффект данных препаратов противоречив и сомнителен. В связи с этим идет активный поиск препаратов метаболитотропного действия.

Цель исследования - установление кардиопротекторного действия индукторов экспрессии и синтеза белков Klotho (витамин D, Necrostatin-1) в условиях моделирования экспериментального инфаркта миокарда.

Экспериментальная часть работы была выполнена на 40 половозрелых крысах - самцах массой 170-210 г. Острый инфаркт миокарда (ОИМ) моделировали путем введения в течение 4 суток питуитрина (1 Ед/кг подкожно) и адреномиметика изопреналина (200 мг/кг внутримышечно). Исследуемые препараты - Витамин D (5000 ME/сутки) (ГмбХ Арцнаймиттель, Германия) вводили внутрижелудочно и Necrostatin-1 (Nec-25 mg, Sigma-Aldrich) 1 мг/кг - внутрибрюшинно через 20 мин после введения изадрина в течение 4 дней. Наличие ОИМ подтверждали путем определения в плазме крови имунохемилюминесцентным методом, Immulate 1000-тропонина (Siemens), биохимическим методом - общей активности креатинфосфокиназы (КФК, Cormay) и иммуноферментным методом - ST2 «The Pressage ST2 Assay» (Critical Diagnostics, № кат. BC-1065E). Детекцию белка Klotho, HSP70 белков, 8-OHdG, ST2 осуществляли на иммуноферментном комплексе Immuno Chem-2100 (США).

Моделирование ОИМ у экспериментальных животных приводило к увеличению маркеров повреждения сердечной мышцы - тропонина, активности общей КФК. Важно отметить, что эти маркеры имели тенденцию к увеличению у животных всех экспериментальных групп по сравнению с интактной. На фоне введения витамина D и Necrostatin-1 значение ST2 не достигали уровня 35 нг/мл. Кроме того, экспериментальная терапия витамином D и Necrostatin-1 приводила к статистически значимому увеличению содержания в гомогенате сердца белка Klotho (соответственно на 76,3 \% и 78,8 \% по отношению к контролю). Применение индукторов синтеза белка Klotho приводило к ограничению окислительного стресса, повреждения нуклеиновых кислот, что проявлялось значительным по сравнению с контролем снижением концентрации 8-OHdG как на фоне витамина D (на 38,5 \%), так и Necrostatin-1 (на 55,8 \%).

Полученные экспериментальные данные обусловливают перспективность дальнейших исследований в этом направлении. Особый интерес вызывает исследование способности витамина D и Necrostatin-1 влиять на процессы клеточной гибели и ее тип (некроз/апоптоз).

Ключевые слова: белок Klotho, витамин D, Necrostatin-1, острый инфаркт миокарда, кардиопротекция 


\section{S. V. Pavlov, J. V. Nikitchenko \\ Cardioprotective effect of Klotho protein syntesis inductors in experimental acute myocardial infarction}

Recent decades have been marked with a global steady growing trend towards an increase in the incidence of vascular diseases linked to the general population aging, and the increasing incidence rate of diabetes mellitus, arterial hypertension and atherosclerosis. Currently, blood flow restorative medications are widely used in the treatment of hypoxic cardio-vascular disorders, along with medications affecting cell metabolism, namely, individual units of the adaptive molecular biochemical reactions. Concerning the efficacy of the last-mentioned medications, a sufficient amount of experimental and clinical data has been cumulated. However, in terms of proof based medicine, the effect of those drugs is controversial and questionable. Therefore, there is an active search for metabolic medications.

The aim of this study was to assess the cardioprotective action of Klotho protein syntesis inductors (vitamin D, Necrostatin-1) in the experimental model of acute myocardial infarction (AMI).

The experimental part was carried out on 40 sexually mature male rats weighing $190-230 \mathrm{~g}$. The AMI was modeled by pituitrin ( 1 unit/kg subcutaneously) and isoprenaline adrenergic agonist (200 mg/kg intramuscularly) injections within 4 days. The study drugs were administrated for 4 days in this way: Vitamin D (5000 IU/day) (GmbH Arzneimittel, Germany) intragastrically and Necrostatin-1 (Nec-25 mg, SigmaAldrich) $1 \mathrm{mg} / \mathrm{kg}$ intraperitoneally $20 \mathrm{~min}$ after isadrin injection. The AMI presence was confirmed by determining its markers in the blood plasma: Immulate 1000 - troponin (Siemens) - by chemiluminescence immuno method, the total CPK activity (Cormay) - by the biochemical method and by the enzyme immunoassay - ST2 «The Pressage ST2 Assay» (Critical Diagnostics, cat. No. BC-1065E). The Klotho protein, HSP70 proteins, 8-OHdG, ST2 were detected with the use of the Immuno Chem-2100 enzymelinked immunosorbent complex (USA).

It has been shown an increase of the markers of heart muscle damage - troponin and total CPK activity in experimental animals under AMI model. It is important to note that these markers tended to increase in animals of all experimental groups in comparison with the intact. The ST2 value did not reach the level of $35 \mathrm{ng} / \mathrm{ml}$ after vitamin D and Necrostatin-1 administration. In addition, vitamin D and Necrostatin-1 experimental therapy resulted in a statistically significant increase of Klotho protein amount in the heart homogenate (by $76,3 \%$ and $78,8 \%$, respectively compared with the control - AMI). The administration of Klotho protein synthesis inducers led to the limitation of oxidative stress, nucleic acid damage, and was reflected by a significant decrease in the concentration of 8-OHdG compared with AMI group, both with the vitamin D (by 38,5\%) and Necrostatin-1 (by 55,8 \%) administration.

The data obtained confirm the viability of further research in this direction. The study of vitamin D and Necrostatin-1 ability to affect the processes of cell death and its type (necrosis/apoptosis) are of special interest in this regard.

Key words: Klotho protein, vitamin D, Necrostatin-1, acute myocardial infarction, cardioprotection

Надійшла: 15 жовтня 2020 р.

Прийнята до друку: 2 грудня 2020 р.

Контактна особа: Павлов Сергій Васильович, Запорізький державний медичний університет, буд. 26, просп. Маяковського, м. Запоріжжя, 69035. Тел.: + 380977970884.

Електронна пошта: svpavlov1980@gmail.com 